University of Nebraska - Lincoln

DigitalCommons@University of Nebraska - Lincoln

Publications, Agencies and Staff of the U.S.

Department of Commerce

U.S. Department of Commerce

2009

\title{
Development and application of DNA techniques for validating and improving pinniped diet estimates
}

Dominic J. Tollit

University of British Columbia, Vancouver, British Columbia V6T 1 Z4 Canada

Angela D. Schulze

Pacific Biological Station, Fisheries and Oceans Canada, 3190 Hammond Bay Road, Nanaimo, British

Columbia V9T 6N7 Canada

Andrew W. Trites

University of British Columbia, Vancouver, British Columbia V6T 1 Z4 Canada

Peter F. Olesiuk

Pacific Biological Station, Fisheries and Oceans Canada, 3190 Hammond Bay Road, Nanaimo, British

Columbia V9T 6N7 Canada

Susan J. Crockford

Pacific IDentifications, 6011 Oldfield Road, Victoria, British Columbia V9E 2J4 Canada

See next page for additional authors

Follow this and additional works at: https://digitalcommons.unl.edu/usdeptcommercepub

Part of the Environmental Sciences Commons

Tollit, Dominic J.; Schulze, Angela D.; Trites, Andrew W.; Olesiuk, Peter F.; Crockford, Susan J.; Gelatt, Thomas S.; Ream, Rolf R.; and Miller, Kristina M., "Development and application of DNA techniques for validating and improving pinniped diet estimates" (2009). Publications, Agencies and Staff of the U.S. Department of Commerce. 205.

https://digitalcommons.unl.edu/usdeptcommercepub/205

This Article is brought to you for free and open access by the U.S. Department of Commerce at DigitalCommons@University of Nebraska - Lincoln. It has been accepted for inclusion in Publications, Agencies and Staff of the U.S. Department of Commerce by an authorized administrator of DigitalCommons@University of Nebraska - Lincoln. 
Authors

Dominic J. Tollit, Angela D. Schulze, Andrew W. Trites, Peter F. Olesiuk, Susan J. Crockford, Thomas S. Gelatt, Rolf R. Ream, and Kristina M. Miller 


\title{
Development and application of DNA techniques for validating and improving pinniped diet estimates
}

\author{
Dominic J. Tollit, ${ }^{1,5}$ Angela D. Schulze, ${ }^{2}$ Andrew W. Trites, ${ }^{1}$ Peter F. Olesiuk, ${ }^{2}$ Susan J. Crockford, ${ }^{3}$ \\ Thomas S. Gelatt, ${ }^{4}$ Rolf R. Ream, ${ }^{4}$ and Kristina M. Miller ${ }^{2}$ \\ ${ }^{1}$ Marine Mammal Research Unit, Fisheries Centre, Aquatic Ecosystems Research Laboratory, 2202 Main Mall, \\ University of British Columbia, Vancouver, British Columbia V6T 1Z4 Canada \\ ${ }^{2}$ Pacific Biological Station, Fisheries and Oceans Canada, 3190 Hammond Bay Road, Nanaimo, British Columbia V9T6N7 Canada \\ ${ }^{3}$ Pacific IDentifications, 6011 Oldfield Road, Victoria, British Columbia V9E 2J4 Canada \\ ${ }^{4}$ National Marine Mammal Laboratory, Alaska Fisheries Science Center, National Marine Fisheries Service, \\ National Oceanic and Atmospheric Administration, 7600 Sand Point Way NE, Seattle, Washington 98115 USA
}

\begin{abstract}
Polymerase chain reaction techniques were developed and applied to identify DNA from $>40$ species of prey contained in fecal (scat) soft-part matrix collected at terrestrial sites used by Steller sea lions (Eumetopias jubatus) in British Columbia and the eastern Aleutian Islands, Alaska. Sixty percent more fish and cephalopod prey were identified by morphological analyses of hard parts compared with DNA analysis of soft parts (hard parts identified higher relative proportions of Ammodytes sp., Cottidae, and certain Gadidae). DNA identified 213 prey occurrences, of which 75 (35\%) were undetected by hard parts (mainly Salmonidae, Pleuronectidae, Elasmobranchii, and Cephalopoda), and thereby increased species occurrences by $22 \%$ overall and species richness in $44 \%$ of cases (when comparing 110 scats that amplified prey DNA). Prey composition was identical within only $20 \%$ of scats. Overall, diet composition derived from both identification techniques combined did not differ significantly from hard-part identification alone, suggesting that past scat-based diet studies have not missed major dietary components. However, significant differences in relative diet contributions across scats (as identified using the two techniques separately) reflect passage rate differences between hard and soft digesta material and highlight certain hypothesized limitations in conventional morphological-based methods (e.g., differences in resistance to digestion, hard part regurgitation, partial and secondary prey consumption), as well as potential technical issues (e.g., resolution of primer efficiency and sensitivity and scat subsampling protocols). DNA analysis of salmon occurrence (from scat soft-part matrix and 238 archived salmon hard parts) provided species-level taxonomic resolution that could not be obtained by morphological identification and showed that Steller sea lions were primarily consuming pink (Oncorhynchus gorbuscha) and chum (Oncorhynchus keta) salmon. Notably, DNA from Atlantic salmon (Salmo salar) that likely originated from a distant fish farm was also detected in two scats from one site in the eastern Aleutian Islands. Overall, molecular techniques are valuable for identifying prey in the fecal remains of marine predators. Combining DNA and hard-part identification will effectively alleviate certain predicted biases and will ultimately enhance measures of diet richness, fisheries interactions (especially salmonrelated ones), and the ecological role of pinnipeds and other marine predators, to the benefit of marine wildlife conservationists and fisheries managers.
\end{abstract}

Key words: denaturing gradient gel electrophoresis (DGGE); diet; DNA; Eumetopias jubatus; fisheries; molecular genetics; North Pacific Ocean; otoliths; pinniped; salmon; scats; Steller sea lion.

\section{INTRODUCTION}

Accurate information about what pinnipeds eat is challenging to obtain, yet vital for assessing the impacts of pinnipeds on prey populations and pinniped interactions with fisheries. Diet studies can be significantly enhanced through incorporation of DNA technologies (Höss et al. 1992, King et al. 2008), with obvious benefits

Manuscript received 12 October 2007; revised 26 March 2008; accepted 14 August 2008; final version received 18 September 2008. Corresponding Editor (ad hoc): M. A. Hindell.

${ }^{5}$ E-mail: Tollit@zoology.ubc.ca to marine wildlife and fisheries managers. Our study develops and applies the polymerase chain reaction (PCR), denaturing gradient gel electrophoresis (DGGE), and DNA sequencing methodology to describe the recent diet of a generalist marine predator, the Steller sea lion (Eumetopias jubatus (Schreber 1776)), while concurrently comparing diet estimated using the conventional, but potentially biased method: morphological identification of diagnostic prey skeletal remains and other hard parts (hence termed "hard-part identification") recovered in fecal (scat) samples (e.g., Olesiuk et al. 1990, Sinclair and Zeppelin 2002, Trites et al. 2007). 
Biomass reconstruction using prey hard parts in scats can theoretically provide useful quantitative estimates of diet for pinnipeds (Bowen 2000, Tollit et al. 2007), but certain key concerns have proved hard to solve (Pierce and Boyle 1991, Tollit et al. 2006), particularly the possibility of not detecting (or severely underestimating) important prey contributions. This may occur if softbodied prey are not represented by hard parts (Olesiuk et al. 1990), if only the fleshy parts of large or spiny prey are consumed (e.g., the bellies of salmon) or if a prey's hard parts are preferentially regurgitated (e.g., cephalopod beaks; see Bigg and Fawcett 1985). Furthermore, prey with robust skeletal elements may be overrepresented compared with prey with fragile skeletons that poorly survive the digestive process (Jobling and Breiby 1986, Murie and Lavigne 1986). In addition, a number of commercially and trophically important prey taxa (notably Salmonidae, Scorpaenidae, and Elasmobranchii) can typically only be identified using hard parts to the family/genera level, rather than the species level.

Recent advances in molecular technologies have already proven useful in a number of marine mammal dietary studies (e.g., Reed et al. 1997, Jarman et al. 2002, Purcell et al. 2004, Ford and Ellis 2006, Casper et al. $2007 b$ ), notably by increasing taxon-level detection rates and improving species resolution. Importantly, captive feeding studies have reliably $(>95 \%)$ detected different prey species fed in varied quantities by extracting prey DNA from scat soft-part matrix (prey flesh remains) and have shown detection of prey is limited to a 48 -h period after feeding (Deagle et al. 2005b). In contrast, passage times of hard parts are far more variable, especially cephalopod beaks, due to long-term retention in the digestive tract (Bigg and Fawcett 1985, Tollit et al. 2003), complicating accurate diet composition estimation. Overall, molecular approaches have the potential to evaluate and alleviate some of the potential biases and limitations associated with reconstructing diets using hard-part identification (e.g., Casper et al. 2007b), but no studies have effectively validated the ability of DNA techniques as a tool to describe general pinniped diet and subsequently contrast these estimates with morphological-based ones.

The Steller sea lion is an ideal species for evaluating new techniques to determine pinniped diets. Intensive dietary studies (using conventional techniques) have been undertaken since the western population of Steller sea lions began its dramatic decline in the 1980s (Loughlin et al. 1992, Trites and Larkin 1996) to assess feeding habits and the extent of dietary overlap with commercial fisheries (e.g., Merrick et al. 1997, Sinclair and Zeppelin 2002, Winship and Trites 2003, Zeppelin et al. 2004). Steller sea lions are generalist feeders, consuming a mix of fish, cephalopods, and crustaceans. Walleye pollock (Theragra chalcogramma) is one of the most common prey (and the basis of the largest fishery) over much of this population's range, yet as a gadid with a robust skeleton and relatively large otoliths, it may be a species whose contribution to the diet (and consequent overlap with fisheries) is presently overestimated. Pacific salmon have relatively fragile skeletons that may lead to being under-represented in traditional diet studies. Nonetheless, salmon have been shown to be important in summer for the endangered western population in the Gulf of Alaska (Sinclair and Zeppelin 2002), and salmon's relative contribution to the diet has been linked with population trends in this area (Sinclair et al. 2005). Pacific salmon is also a top-ranked species in the diet of Steller sea lions in the eastern part of their range, southeast Alaska and British Columbia (Winship and Trites 2003, Trites et al. 2007; A. W. Trites and P. F. Olesiuk, unpublished data). However, the actual salmon species most important to Steller sea lions in the North Pacific is largely unknown due to the scarcity of otoliths recovered in good condition and the difficulties in species differentiation using other eroded hard parts.

Our study sought to evaluate and apply molecular techniques to improve the determination of the diet of Steller sea lions, using scats collected from the wild. Specifically, we aimed to (1) optimize techniques and evaluate efficiencies of DNA extraction from scat material, (2) develop a genetically based iterative prey species analysis that allows for identifying more than 30 key prey species (or species groupings) from scat softpart matrix as well as individual species within the family Salmonidae using archived hard parts, and (3) compare and contrast DNA diet results with those based on morphological hard-part identification to evaluate sources and levels of bias.

\section{Methodology}

\section{Scat collection and prey hard-part identification analysis}

We collected 142 individual scat samples from rock substrate sites in British Columbia (BC), Canada ( $n=$ $70)$, and the eastern Aleutian Islands (EA), Alaska ( $n=$ 72; Fig. 1, Table 1). Most scats were soft and moist and considered fresh/recent (less than a few days old) when collected, but in both regions 20 desiccated "old" scats (considered one to two weeks old) were collected to assess the feasibility of prey DNA extraction from scats in different conditions.

Subsamples of scat soft-part matrix for DNA analysis were preserved within $24 \mathrm{~h}$ by gently pressing homogenized scat slurry through individual $0.5-\mathrm{mm}$ plastic mesh sections using a disposable spatula and $2-3 \mathrm{~mL}$ of matrix material scraped from the underside (i.e., no hard parts were collected) and placed in $\sim 15 \mathrm{~mL}$ of $95 \%$ ethanol (non-denaturing). Individual scats and each associated mesh were subsequently machine-washed (Orr et al. 2003), and all retained hard parts were identified based on diagnostic morphological criteria to the lowest possible taxonomic group by Pacific IDentifications (using comparative reference skeletons at the University of Victoria Anthropology Department, Vic- 


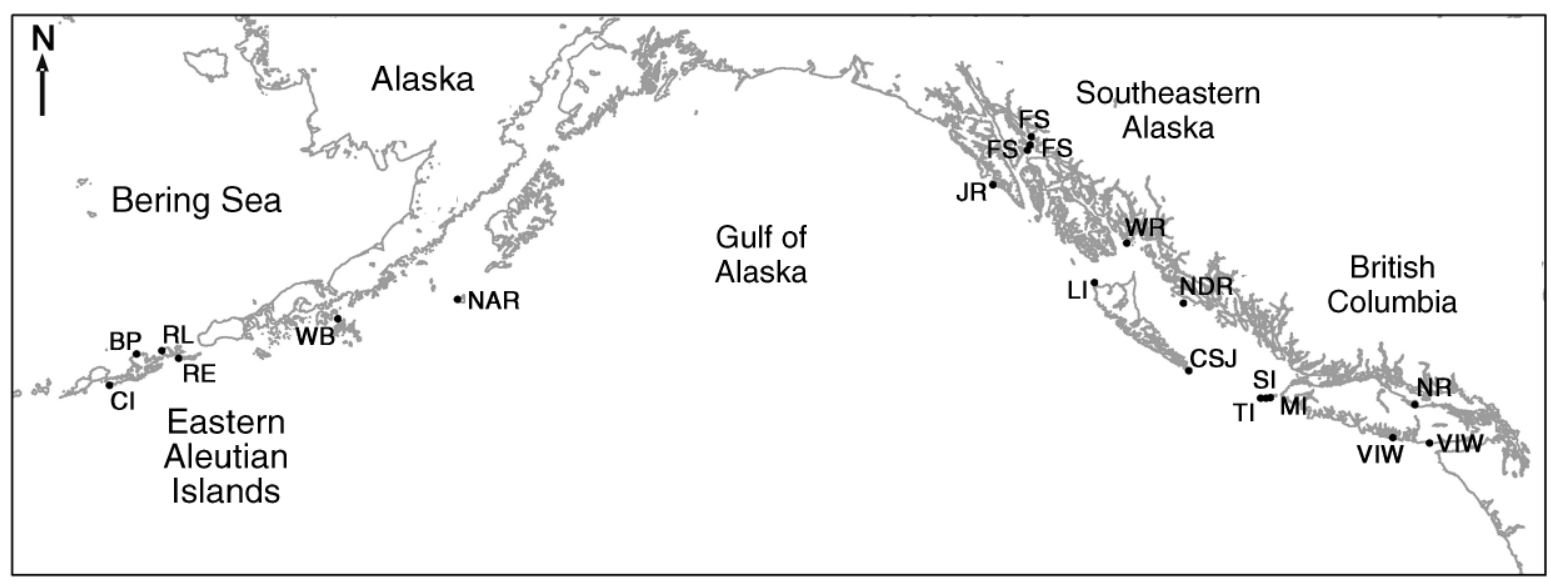

FIG. 1. Steller sea lion scat collection site locations (see Table 1 for site code descriptions).

toria, BC), a firm that identifies prey hard parts for most scientists working on the diet of Steller sea lions (e.g., Sinclair and Zeppelin 2002, Tollit et al. 2004, Trites et al. 2007).

Archived scat hard parts from BC (1997-2001, $n=67)$ and southeastern Alaska (2001-2002, $n=33$; Fig. 1, Table 1) identified as Salmonidae were measured and photographed prior to undertaking genetic species identification using up to four hard parts from each scat (see Species identification from archived Salmonidae...).

\section{Molecular techniques methodology and validation}

We needed to develop a molecular technique that could identify a wide range of potential prey species (i.e., fish, cephalopods, and crustaceans) in various aged scats collected from wild sea lion populations, as well as one that allowed the separation and identification of multiple prey species within one scat sample. The technique also had to be scaleable to efficiently analyze large numbers of scat samples from wild populations. The PCR-DGGE method met these criteria (see Myers et al. 1987, King et al. 2008) and therefore was chosen.

The DNA from scats is expected to be somewhat degraded (particularly from the more aged samples) and contain a range of concentrations derived from prey and host sources. Therefore, it was essential to design PCR primers to amplify a small fragment $(\sim 200-300$ base pairs [bp]) and to design nested primers (two internal secondary primers) or semi-nested primers (one internal secondary primer) for two rounds of amplification in order to obtain enough specific product for visualization.

The well-characterized $3^{\prime}$ end of the mitochondrial $16 \mathrm{~S}$ gene was chosen to allow species identification through sequencing and submission to the National Center for Biotechnology Information (NCBI; Bethesda, Maryland, USA) Basic Local Alignment Search Tool (BLAST). After comparison of available GenBank $16 \mathrm{~S}$ sequence alignments (Benson et al. 2005) for potential prey species, it was determined that the amplification of a small fragment (280-300 bp) from a wide range of fish species was possible with a 1-bp modification to the reverse primer $(16 \mathrm{~S} 2 \mathrm{R})$ of previously designed semi-nested primers (Deagle et al. 2005b; Table 2, Appendix A). The universal primers (16SF1 and 16SallR; Table 2) were used in a primary PCR to amplify prey DNA in scat, while a fish-specific seminested set of secondary primers (16SfishF $[8 \mathrm{bp}$ internal to $16 \mathrm{SF} 1$ and less conserved region of the $16 \mathrm{~S}$ gene] and 16SallRcl; Table 2) were used to further amplify the minute quantities of prey DNA while eliminating the amplification of DNA from the host sea lion and other non-fish species (Jarman et al. 2004). Following this, the primer-binding capability of the semi-nested primers was validated for a set of 68 potential fish prey species from BC and Alaska as outlined in Table 3 and Appendices B and C.

Since amplification of potential cephalopod and crustacean prey was not possible using the semi-nested fish-specific set of primers (mismatches in $16 \mathrm{SfishF}$ primer in cephalopods and mismatches in 16SallR and 16 SfishF in crustaceans), new PCR primers were designed to identify these groups (Appendix A). Two cephalopod-specific secondary primers (16ScephF-specific for squid and $16 \mathrm{ScephF}$ (b)-specific for octopus) as well as crustacean-specific primary (16ScrustR) and secondary primers (16ScrustF) were designed based on available GenBank multiple $16 \mathrm{~S}$ crustacean and cephalopod sequence alignments (Benson et al. 2005) (Table 2). Again, primer-binding capability of these primer sets was validated on the extracted cephalopod (3) and crustacean (4) samples, and the amplification of these prey items was carried out as outlined in Table 3 and Appendix B.

Denaturing gradient gel electrophoresis is a sequencedependent electrophoretic technique that separates amplification products based on their melting behavior as they denature and can discern as little as $1 \mathrm{bp}$ of difference in sequence between two samples that may be missed in sequencing alone and can be utilized efficiently 
TABLE 1. Date, region, and site information for Steller sea lion scat collections used in DNA analyses.

\begin{tabular}{|c|c|c|c|c|}
\hline $\begin{array}{l}\text { Date by } \\
\text { region }\end{array}$ & Scat collection site (code) & DNA method applied to & Scat $(n)$ & Salmon hard parts $(n)$ \\
\hline \multicolumn{5}{|l|}{ EA } \\
\hline May 2005 & Nagai Rocks (NAR) & scat matrix & 10 & $\mathrm{n} / \mathrm{a}$ \\
\hline May 2005 & Rotock East (RE) & scat matrix & 10 & $\mathrm{n} / \mathrm{a}$ \\
\hline May 2005 & Bishop Point (BP) & scat matrix & 20 & $\mathrm{n} / \mathrm{a}$ \\
\hline May 2005 & The Whaleback (WB) & scat matrix & 10 & $\mathrm{n} / \mathrm{a}$ \\
\hline May 2005 & Reef-Lava (RL) & scat matrix & 12 & $\mathrm{n} / \mathrm{a}$ \\
\hline May 2005 & Cape Izigan (CI) & scat matrix & 10 & $\mathrm{n} / \mathrm{a}$ \\
\hline \multicolumn{5}{|l|}{$\mathrm{BC}$} \\
\hline Mar 2005 & Norris Rocks (NR) & scat matrix & 20 & $\mathrm{n} / \mathrm{a}$ \\
\hline Jul 2005 & Sartine Island (SI) & scat matrix & 20 & $\mathrm{n} / \mathrm{a}$ \\
\hline Jul 2005 & Langara Island (LI) & scat matrix & 10 & $\mathrm{n} / \mathrm{a}$ \\
\hline Jul 2005 & North Danger Rocks (NDR) & scat matrix & 20 & $\mathrm{n} / \mathrm{a}$ \\
\hline Jun 1997 & Maggot Island (MI) & hard parts & 9 & 27 \\
\hline Jun 2000 & Triangle Island (TI) & hard parts & 6 & 9 \\
\hline Jul 2000 & Sartine Island (SI) & hard parts & 9 & 19 \\
\hline Jul 2000 & Cape St. James (CSJ) & hard parts & 11 & 25 \\
\hline Jun 2001 & Vancouver Island West (VIW) & hard parts & 3 & 7 \\
\hline Jul 2001 & Sartine Island (SI) & hard parts & 29 & 65 \\
\hline \multicolumn{5}{|l|}{ SEAK } \\
\hline May 2001 & Frederick Sound (FS) & hard parts & 2 & 6 \\
\hline Jun 2001 & West Rocks (WR) & hard parts & 1 & 4 \\
\hline Jun 2001 & Jacob Rocks (JR) & hard parts & 2 & 5 \\
\hline Jul 2001 & Frederick Sound (FS) & hard parts & 1 & 4 \\
\hline Sep 2001 & Frederick Sound (FS) & hard parts & 14 & 38 \\
\hline Dec 2001 & Frederick Sound (FS) & hard parts & 9 & 24 \\
\hline May 2002 & Frederick Sound (FS) & hard parts & 4 & 5 \\
\hline All & All sites & all & 242 & 238 \\
\hline
\end{tabular}

Notes: Also included is a summary of the species of Salmonidae identified based on DNA methods applied to (1) scat soft-part matrix (scat matrix) in the prey identification method comparison study and (2) Salmonidae hard parts (Salmon hard parts, $n=$ 238) selected from 100 archived sea lion scat contents. Abbreviations for regions are: EA, eastern Aleutian Islands; BC, British Columbia; SEAK, southeastern Alaska. The abbreviation "n/a" means "not applicable."

$\uparrow$ Two scats were identified as Atlantic salmon.

\$ This scat was identified as Arctic char.

$\S$ These hard parts were not identified to a single species, but rather to pink or coho salmon.

I| These hard parts were identified as Salmonidae using morphological characteristics; however, they were identified as other taxa by DNA (including two arrowtooth flounder, one Pacific herring, one Pacific lingcod, one Southern rock sole, one rockfish, one staghorn sculpin, and one California headlight fish).

to determine the number of unique items (alleles) within one sample (PCR). Therefore, to establish the species reference databases herein, DGGE, along with sequencing validation, was applied to all of the supplied prey samples and scats. This rigorous validation was used for "proof of concept," and we expect future scat analyses to be largely carried out based on DGGE banding patterns alone, with less intensive sequencing validation. Our technique could also resolve "unknown prey," allowing prey species catalogues and standards to be continuously updated.

\section{Prey DNA standards}

Tissue samples from 75 potential sea lion prey species, including fish (68), cephalopods (3), and crustaceans (4), with multiple individuals per species in a majority of the samples, were used by the Molecular Genetics Laboratory (MGL) at the Pacific Biological Station (Nanaimo, $\mathrm{BC}$, Canada) to validate PCR primers, develop optimal species resolution conditions, and provide prey standards to aid in initial prey identification. All prey items were extracted following the Qiagen DNeasy 96 tissue kit instructions (Qiagen, Germantown, Maryland, USA). Extracted prey DNA was amplified using the semi-nested $16 \mathrm{~S}$ primer sets as outlined above and detailed in Table 3 and Appendix B. Upon determination that all fish species provided amplified PCR product using the semi-nested primers, each was re-amplified with only the external (primary) primer set (Tables 2 and 3) for sequence confirmation and the production of standards. The PCR reactions were purified using the QIAquick PCR purification kit (Qiagen; see Appendix B for detailed genetic techniques). Sequences of the prey samples were submitted to the National Centre for Biotechnology Information Basic Local Alignment Search Tool (BLAST) and compared with those available for identity confirmation. High-scoring matches $(98 \%$ or greater) were considered species identities (Appendix C).

For fish, cephalopods, and crustaceans, standard sets of prey bands of known sequence identity were developed and run in multiple positions on each DGGE 
TABLE 1. Extended.

\begin{tabular}{|c|c|c|c|c|c|c|c|}
\hline \multirow[b]{2}{*}{ (Region) } & \multicolumn{6}{|c|}{ Species of Salmonidae identified by DNA methods } & \multirow{2}{*}{$\begin{array}{l}\text { Other species } \\
\text { (not salmon) }\end{array}$} \\
\hline & Chum & Pink & Coho & Chinook & Sockeye & Mixed species & \\
\hline \multicolumn{8}{|l|}{ (EA) } \\
\hline & 1 & & & & 0 & & \\
\hline & 2 & & & & & 0 & \\
\hline & 1 & & & & 1 & 0 & \\
\hline & 1 & & & & & $2 \dagger$ & \\
\hline & 4 & & & & 1 & $1 \ddagger$ & \\
\hline & 1 & & & & & 0 & \\
\hline \multicolumn{8}{|l|}{ (BC) } \\
\hline & & & 4 & & 0 & & \\
\hline & 2 & 3 & 1 & 1 & 2 & 0 & \\
\hline & & & 1 & & 0 & & \\
\hline & 2 & 15 & & 1 & & 0 & \\
\hline & 5 & 1 & 2 & & 3 & 1 & 1 \\
\hline & 5 & 1 & & & 0 & & \\
\hline & 3 & 3 & & 2 & 2 & 0 & 1 \\
\hline & 2 & 4 & 1 & 3 & 1 & 1 & 1 \\
\hline & 1 & & 1 & 1 & & 0 & \\
\hline & 19 & 7 & 3 & 2 & 2 & 7 & 3 \\
\hline \multicolumn{8}{|l|}{$(\mathrm{SEAK})$} \\
\hline & 1 & & 1 & 1 & 2 & & \\
\hline & 1 & & & & & 0 & \\
\hline & 1 & 1 & & & & 0 & \\
\hline & & & 1 & & 0 & & \\
\hline & 8 & 7 & & & $4 \S$ & 1 & \\
\hline & 4 & & 4 & & 3 & 1 & \\
\hline & 1 & & 1 & 1 & 1 & & \\
\hline (All) & 45 & 54 & 16 & 21 & 14 & 22 & $8 \|$ \\
\hline
\end{tabular}

gel to enable genotyping based on the position of the prey bands relative to the standard set under all appropriate conditions. A 5' guanine-cytosine (GC) clamp was applied to the reverse primers (Table 2) to increase sensitivity of the DGGE analysis (Myers et al. 1985). Due to the number of species and alleles in the prey inventory (72 in total), three standard sets were generated, incorporating 27, 24, and 21 alleles, for sets 1-3, respectively. Each standard set consisted of three lanes labelled A, B, and C (see Fig. 2 for standard set 1). The standard sets were assembled based on rankings of the prey (i.e., those thought to be most commonly consumed) and their corresponding band position on DGGE, thus maximizing the band resolution as well as the number of key species identifiable on a single gel.

\section{Prey DNA identification from scat soft-part matrix}

DNA extractions were performed on scat soft-part matrix following the protocol outlined in Deagle et al. (2005a), with the amplification and PCR-DGGE conditions listed in Tables 2 and 3 (see Appendix B for more detailed PCR recipes). The extracted samples were first amplified with a general PCR primer pair (amplifies fish and cephalopods) and a primer pair specific to crustaceans. Semi-nested PCRs were subsequently performed using $2 \mu \mathrm{L}$ of the primary PCR reaction as template with forward primers fluorescently labelled with 6-FAM (fish), NED (cephalopods), and ROX (crustaceans) (Operon Biotechnologies, Huntsville, Alabama, USA; Applied Biosystems, Foster City, California, USA) for visualization of products. These three semi-nested, distinctly labeled PCRs were then pooled and electrophoresed together on two DGGE gels, one at $56^{\circ} \mathrm{C}$ (sensu Deagle et al. 2005b) and the other at $60^{\circ} \mathrm{C}$ (Fig. 2, Table 3). Running two variations in temperature was an important additional step that aided in the resolution of prey using DGGE techniques. Banding patterns of each scat run at each temperature on the DGGE gels were compared to the migration of prey standards run in one lane for cephalopods and crustaceans and nine lanes (three sets of A, B, and C standard lanes) for fish. Scat bands matching a prey standard under both running conditions were tentatively identified as matches, while bands that did not match prey standards at one or both conditions were labeled "unknowns" and their relative migratory position to the standards was noted. Fish standard set 1 (containing the highest ranking fish prey items) was run first, followed by standard sets 2 and 3 if unidentified prey remained.

To confirm and expand DGGE identity assignments (i.e., both matches and unknowns), all bands in all amplified scat samples were excised from the gels, PCR purified, and sequenced. To accomplish this, each scat sample was re-amplified with the appropriate primer sets and re-run on DGGE leaving a lane between samples. The excised gel slices were added to $50 \mu \mathrm{L}$ of sterile, 
TABLE 2. Sequences of primers $\left(5^{\prime}-3^{\prime}\right)$ used to analyze the content of the scat soft-part matrix.

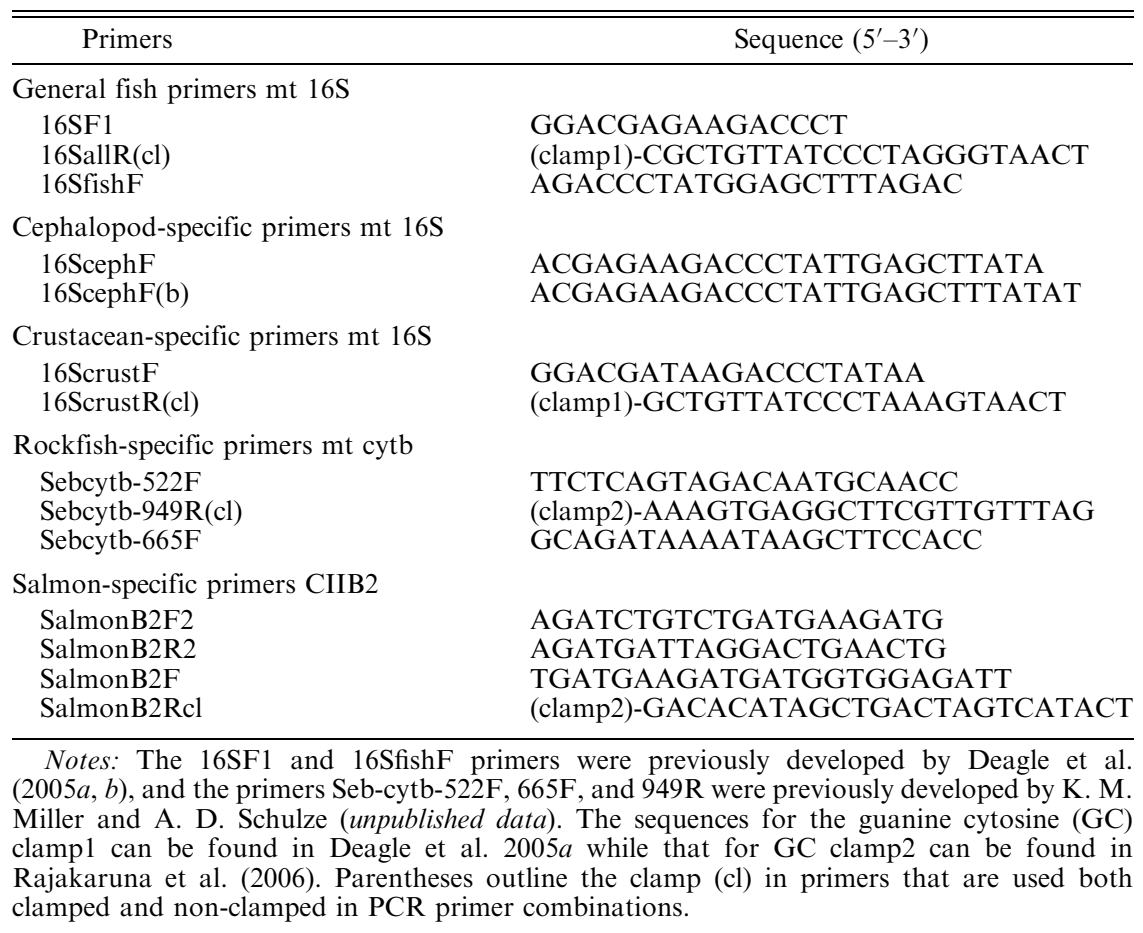

distilled water and exposed to two rounds of freeze/ thawing, and $2 \mu \mathrm{L}$ of each was used as template in a subsequent semi-nested PCR (Table 3). To confirm band identity, each was re-run next to their corresponding scat sample as a control (Table 3). Sequencing reactions were performed after PCR purifications, and sequences of bands assigned DGGE identifications based on band migration matches were compared with the matching species standard. Sequences of bands that were not identified through standards were identified through BLAST searches.

\section{Additional species-specific identification of Salmonidae and Scorpaenidae in scat soft-part matrix}

Salmonidae and Scorpaenidae (rockfish/scorpionfish) are both diverse families represented by numerous species. Hence, after tentative identifications based on $16 \mathrm{~S}$ matches were assigned, scats were re-amplified with nested sets of Salmonidae-specific (based on the major histocompatibility complex [MHC] class II B2 gene exon) and Scorpaenidae-specific (based on the mitochondrial cytochrome $\mathrm{b}$ [cytb] gene) primers to provide secondary species presence confirmation (Table 2). The Salmonidae B2 primers were designed based on multiple sequence alignments of the MHC class II B2 genes (Miller and Withler 1996) in seven salmon species. For the design of primers for the Scorpaenidae group, multiple sequence alignments from available corresponding cytochrome b sequences in GenBank (Benson 2005) were analyzed. Primers were designed to amplify a region of $\sim 1400 \mathrm{bp}$ in length (including a majority of the cytb gene (minus $254 \mathrm{bp}$ at the $5^{\prime}$ end) as well as $\sim 350$ bp of the $5^{\prime}$ end of the control region (CR) (K. M. Miller and A. D. Schulze, unpublished data). Multiple primer combinations spanning regions $(250-350 \mathrm{bp}$ in size) internal to this (K. M. Miller and A. D. Schulze, unpublished data) were also designed for PCR-DGGE species identification applications. Eleven identified rockfish species (most not included in GenBank) were amplified with the external primers and sequenced to confirm primer binding regions for the internal primers and to establish sequence and corresponding DGGE databases (K. M. Miller and A. D. Schulze, unpublished data). Based on the conserved and species-specific regions of the cytb sequences, along with their ability to differentiate the tested species, the primers listed in Table 2 were chosen for application in our study and applied in combination as listed in Table 3 (see Appendix B for PCR recipes). Samples were run on DGGE under their appropriate conditions (Table 3), and a subset of products representing unique banding migration patterns were excised and sequenced.

\section{Species identification from archived Salmonidae hard parts using genetic techniques}

A total of 239 suitable Salmonidae hard parts (including vertebrae, gillrakers, radials, teeth, and branchials, the most commonly identified recovered hard parts of salmon) were bleached in $10 \%$ sodium hypochlorite solution for $10 \mathrm{~min}$ and then rinsed in sterile water prior to DNA extraction to destroy any external contaminating DNA. To aid in hard-tissue 
TABLE 3. Polymerase chain reaction-denaturing gradient gel electrophoresis (PCR-DGGE) conditions used to analyze the content of the scat soft-part matrix.

\begin{tabular}{|c|c|c|c|}
\hline Primer combinations & $\begin{array}{l}\text { Amplicon } \\
\text { size (bp) }\end{array}$ & PCR conditions & $\begin{array}{l}\text { DGGE } \\
\text { conditions }\end{array}$ \\
\hline \multicolumn{4}{|l|}{ General and fish-specific $\mathrm{mt} 16 \mathrm{~S}$ gene } \\
\hline \multicolumn{4}{|l|}{ Primary } \\
\hline \multirow[t]{3}{*}{$16 \mathrm{SF} 1 \times 16$ SallR } & 290-308 & $95^{\circ} \mathrm{C} / 15^{\prime}$ & \\
\hline & & $\begin{array}{l}94^{\circ} \mathrm{C} / 30^{\prime \prime} 56^{\circ} \mathrm{C} / 30^{\prime \prime} \\
72^{\circ} \mathrm{C} / 1^{\prime} \text { for } 20 \text { cycles }\end{array}$ & \\
\hline & & $72^{\circ} \mathrm{C} / 10^{\prime}$ & \\
\hline \multicolumn{4}{|l|}{ Semi-nested } \\
\hline \multirow[t]{3}{*}{ 16SfishF-6FAM $\times 16$ SallRcl } & $282-300$ & $95^{\circ} \mathrm{C} / 15^{\prime}$ & $35-60 \%$ denaturant ( $7.5 \%$ acrylamide) \\
\hline & & $\begin{array}{l}94^{\circ} \mathrm{C} / 30^{\prime \prime} 55^{\circ} \mathrm{C} / 30^{\prime \prime} \\
72^{\circ} \mathrm{C} / 45^{\prime \prime} \text { for } 35 \text { cycles }\end{array}$ & $60 \mathrm{~V}$ for $15 \mathrm{~h}$ at $56^{\circ} \mathrm{C}$ and $60^{\circ} \mathrm{C}$ \\
\hline & & $72^{\circ} \mathrm{C} / 10^{\prime}$ & \\
\hline \multicolumn{4}{|l|}{ Cephalopod-specific mt $16 \mathrm{~S}$ gene } \\
\hline \multicolumn{4}{|l|}{ Primary } \\
\hline $16 \mathrm{SF} 1 \times 16$ SallR & $199-233$ & same as above & \\
\hline \multicolumn{4}{|l|}{ Semi-nested } \\
\hline \multirow[t]{3}{*}{$16 \mathrm{ScephF} / \mathrm{F}(\mathrm{b})-\mathrm{NED} \times 16 \mathrm{SallRcl}$} & $191-225$ & $95^{\circ} \mathrm{C} / 15^{\prime}$ & \\
\hline & & $\begin{array}{l}94^{\circ} \mathrm{C} / 30^{\prime \prime} 55^{\circ} \mathrm{C} / 30^{\prime \prime} \\
72^{\circ} \mathrm{C} / 45^{\prime \prime} \text { for } 35 \text { cycles }\end{array}$ & $60 \mathrm{~V}$ for $15 \mathrm{~h}$ at $56^{\circ} \mathrm{C}$ and $60^{\circ} \mathrm{C}$ \\
\hline & & $72^{\circ} \mathrm{C} / 10^{\prime}$ & \\
\hline \multicolumn{4}{|l|}{ Crustacean-specific mt16S gene } \\
\hline \multicolumn{4}{|l|}{ Primary } \\
\hline \multirow[t]{3}{*}{$16 \mathrm{SF} 1 \times 16$ ScrustR } & $200-214$ & $95^{\circ} \mathrm{C} / 15^{\prime}$ & \\
\hline & & $\begin{array}{l}94^{\circ} \mathrm{C} / 30^{\prime \prime} 50^{\circ} \mathrm{C} / 30^{\prime \prime} \\
68^{\circ} \mathrm{C} / 1^{\prime} \text { for } 20 \text { cycles }\end{array}$ & \\
\hline & & $72^{\circ} \mathrm{C} / 10^{\prime}$ & \\
\hline \multicolumn{4}{|l|}{ Semi-nested } \\
\hline \multirow[t]{3}{*}{ 16ScrustF-ROX $\times 16$ ScrustRcl } & $200-214$ & $95^{\circ} \mathrm{C} / 15^{\prime}$ & \\
\hline & & $\begin{array}{l}94^{\circ} \mathrm{C} / 30^{\prime \prime} 50^{\circ} \mathrm{C} / 30^{\prime \prime} \\
68^{\circ} \mathrm{C} / 1^{\prime} \text { for } 35 \text { cycles }\end{array}$ & $60 \mathrm{~V}$ for $15 \mathrm{~h}$ at $56^{\circ} \mathrm{C}$ and $60^{\circ} \mathrm{C}$ \\
\hline & & $72^{\circ} \mathrm{C} / 10^{\prime}$ & \\
\hline \multicolumn{4}{|l|}{ Salmon-specific CIIB2 MHC gene } \\
\hline \multicolumn{4}{|l|}{ Primary } \\
\hline \multirow{3}{*}{ SalmonB2F2 $\times$ SalmonB2R2 } & $291-306$ & $95^{\circ} \mathrm{C} / 15^{\prime}$ & \\
\hline & & $\begin{array}{l}94^{\circ} \mathrm{C} / 1^{\prime} 55^{\circ} \mathrm{C} / 1^{\prime} \\
72^{\circ} \mathrm{C} / 2^{\prime} \text { for } 20 \text { cycles }\end{array}$ & \\
\hline & & $72^{\circ} \mathrm{C} / 10^{\prime}$ & \\
\hline \multicolumn{4}{|l|}{ Nested } \\
\hline \multirow[t]{3}{*}{ SalmonB2F-ROX $\times$ SalmonB2Rcl } & $258-273$ & $95^{\circ} \mathrm{C} / 15^{\prime}$ & $35-60 \%$ denaturant ( $7.5 \%$ acrylamide) \\
\hline & & $\begin{array}{l}94^{\circ} \mathrm{C} / 1^{\prime} 55^{\circ} \mathrm{C} / 1^{\prime} \\
72^{\circ} \mathrm{C} / 2^{\prime} \text { for } 35 \text { cycles }\end{array}$ & $60 \mathrm{~V}$ for $15 \mathrm{~h}$ at $53.5^{\circ} \mathrm{C}$ \\
\hline & & $72^{\circ} \mathrm{C} / 10^{\prime}$ & \\
\hline \multicolumn{4}{|l|}{ Rockfish-specific mt cytb gene } \\
\hline \multicolumn{4}{|l|}{ Primary } \\
\hline \multirow[t]{3}{*}{ Sebcytb-522F $\times$ Sebcytb-949R } & 427 & $95^{\circ} \mathrm{C} / 15^{\prime}$ & \\
\hline & & $\begin{array}{l}94^{\circ} \mathrm{C} / 1^{\prime} 50^{\circ} \mathrm{C} / 1^{\prime} \\
68^{\circ} \mathrm{C} / 2^{\prime} \text { for } 20 \text { cycles }\end{array}$ & \\
\hline & & $72^{\circ} \mathrm{C} / 10^{\prime}$ & \\
\hline \multicolumn{4}{|l|}{ Semi-nested } \\
\hline \multirow[t]{3}{*}{ Sebcytb-665F-6FAM $\times$ Sebcytb-949Rcl } & 284 & $95^{\circ} \mathrm{C} / 15^{\prime}$ & $35-60 \%$ denaturant ( $7.5 \%$ acrylamide) \\
\hline & & $\begin{array}{l}94^{\circ} \mathrm{C} / 1^{\prime} 50^{\circ} \mathrm{C} / 1^{\prime} 68^{\circ} \mathrm{C} / 2^{\prime} \\
\text { for } 35 \text { cycles }\end{array}$ & $60 \mathrm{~V}$ for $15 \mathrm{~h}$ at $58^{\circ} \mathrm{C}$ \\
\hline & & $72^{\circ} \mathrm{C} / 10^{\prime}$ & \\
\hline
\end{tabular}

Note: The amplicon sizes in the text do not include the 39-base pair (bp) clamp1 or 40-bp clamp2. 


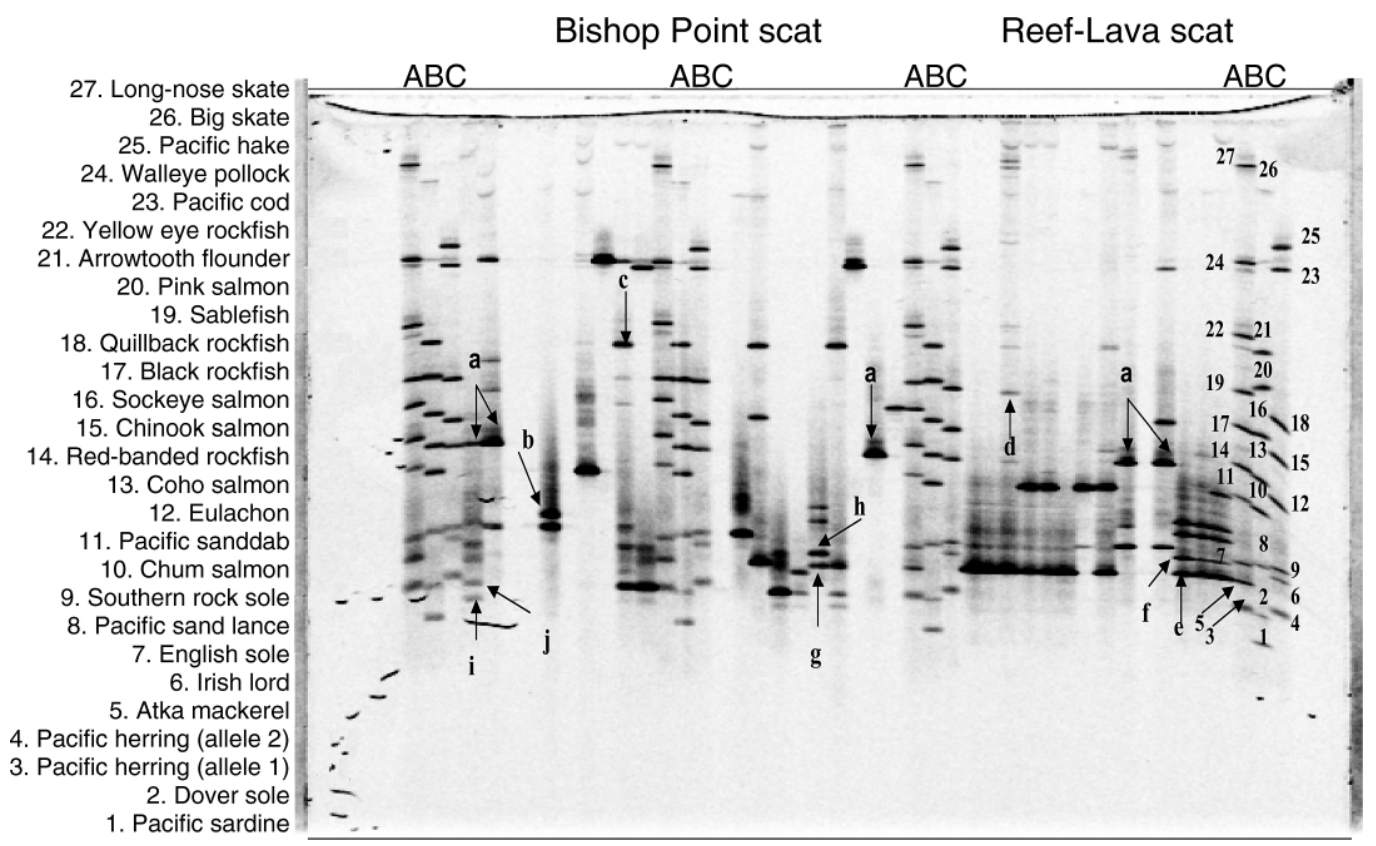

FIG. 2. Polymerase chain reaction-denaturing gradient gel electrophoresis (PCR-DGGE) profiles $\left(60^{\circ} \mathrm{C}\right.$ run) in scats from two different eastern Aleutian Island Steller sea lion haul-out sites: Bishop Point $(n=20)$ and Reef-Lava $(n=14)$. Scats were amplified between three sets of 16 Sfish standards (set 1 shown), labeled as A, B, and C. Both sites also share a new prey item, smooth lumpsucker (labeled "a"). The Bishop Point scats contain five unique prey, lemon sole, rex sole, walleye pollock, unidentified sculpin (labeled "b"), and winter flounder (labeled "c"). The Reef-Lava site contains one new, unique prey item, arctic char (labeled "d"). Three fish prey, Atka mackerel (labeled "e" and "f"), lemon sole (labeled "g" and "h"), and Rex sole (labeled "i" and "j") contain more than one allele in a single scat (likely indicative of multiple fish).

homogenization, a mixer mill set at $30 \mathrm{~Hz}$ for 2 min was applied after freezing the hard parts along with a single 5 -mm steel mixer mill ball at $-80^{\circ} \mathrm{C}$ for at least $1 \mathrm{~h}$. Following this, DNA was extracted using the DNeasy tissue kit. The 16S and MHC CII B2 amplifications of Salmonidae hard parts were analyzed via PCR-DGGE, and the identifications obtained from both markers were used to establish species identification. Samples for which the results were inconclusive or for which the two gene marker identifications for one hard part did not match were sequenced.

\section{Comparison of prey occurrences using morphological hard-part and soft-part DNA identification}

Diet composition (fish and cephalopods, hence termed "prey") using morphological hard-part identification and prey DNA identified within the soft-part matrix of the same scats were compared (for each region) using occurrence (presence/absence) measures (Statview 5.0.1, SAS Institute, Cary, North Carolina, USA). To allow direct comparison, frequency of occurrence (FO) was modified, whereby FO values were down-weighted so that, summed across all prey types, they totaled $100 \%$, an index termed "modified frequency of occurrence" (MFO; Bigg and Perez 1985). It is important to note that for this comparison, no DNA identification of any hard parts was undertaken. We sought to compare diet determined from digested prey flesh in scats (using DNA methods) with diet determined from identifiable prey skeletal hard-part remains.

Prey species were grouped when species-specific information was not consistently available across both techniques or for very uncommon species occurrences. Groups typically included appropriate family groupings (e.g., Cottidae, Liparidae, Salmonidae), subfamily groupings (Pleuronectidae [flatfish]), subclasses and class groupings (Elasmobranchii [rays, skates, and sharks] and Cephalopoda [octopus and squid], respectively), as well ecological or residual groups of species (i.e., other Gadidae, other forage fish). (See Appendix D for details of the 22 prey group categories and the Latin name of individual species.) In cases for which heterozygous alleles were detected, only one occurrence was counted.

The two different identification techniques were also compared on a scat-by-scat basis to determine how often species occurrences matched and to what extent the inclusion of prey DNA data increased (1) species richness in scats (i.e., additional prey species incidences for which hard-part identification had found no evidence) and (2) species resolution (i.e., improved prey species identification, typically in cases in which hard parts were identified with certainty down to the family level and DNA identification methods subsequently resolved identification to the species level). Species richness criteria were deliberately conservative, requiring incidences dissimilar beyond the family, subfamily (for 
flatfish), or (sub)class level (for Cephalopoda and Elasmobranchii). Note that crustacean species identified though DNA identification alone were not included in these comparisons as they are often considered secondary prey and consequently are not regularly reported using morphological hard-part identification criteria.

\section{RESULTS}

\section{Prey DNA standards}

In order to identify prey within sea lion scat soft-part matrix using molecular techniques (PCR-DGGE; Tables 2 and 3), 72 prey species profiles of the $16 \mathrm{~S}$ gene were developed. (A complete list of prey items with Latin form names is available on the Fisheries and Oceans Canada PBS Molecular Genetics Laboratory web site.) ${ }^{6}$ For prey fish species that had corresponding 16S gene sequences in GenBank, the semi-nested $16 \mathrm{~S}$ primer sequences typically displayed $100 \%$ forward and reverse primer matches. Mismatches between primer and template can potentially affect amplification success but may be tolerated, unless they are located at the primer $3^{\prime}$ end, which typically was not the case. Those that displayed one mismatch in the forward primer set (16SfishF) included California headlightfish, grunt sculpin, and Pacific sardine, as well as some Elasmobranchii. Brokenline lampfish displayed two mismatches in the forward primer set (16SfishF), while yellowfin sole displayed one mismatch in the reverse primer set (16SallR). Four species displayed mismatches in both of the primers: bay pipefish ( $3 \mathrm{bp}$ in $16 \mathrm{SfishF}$ and $1 \mathrm{bp}$ in 16SallR), northern lampfish (3 bp in 16SfishF and $2 \mathrm{bp}$ in 16SallR), Pacific hake ( $1 \mathrm{bp}$ in $16 \mathrm{SfishF}$ and in 16SallR), and Pacific sanddab (2 bp in 16SfishF and $1 \mathrm{bp}$ in 16SallR). However, all of the prey samples provided were successfully amplified from controls in semi-nested (double-amplified) PCRs, although dogfish, skate, and Pacific sanddab bands were weaker than those of other species and the Pacific herring bands appeared fuzzy but were recognizable. No obvious non-heterodimer cryptic bands were observed. Multiple individuals were provided for $72 \%$ of the fish species in the prey inventory, $26 \%$ of which contained more than one allele. Eleven of the prey species displayed two $16 \mathrm{~S}$ alleles differentiated on DGGE, including California headlight fish, Dover sole, English (lemon) sole, great sculpin, kelp greenling, lingcod, Pacific herring, Pacific sardine, sablefish, sand sole, and yellowfin sole, and one, Pink salmon, displayed three alleles. A few species were difficult to differentiate via DGGE, although they could be differentiated by sequencing (or potentially via fragment size analysis), notably rex sole (300 bp) from one Pacific herring allele (286 bp) and Pacific halibut (300 bp) from one English sole allele (300 bp). One pink salmon allele and one sockeye salmon allele (288 bp) with distinctive 16S sequences were not differentiated under either set of

\footnotetext{
${ }^{6}\langle$ http://www.pac.dfo-mpo.gc.ca/sci/mgl/default_e.htm $\rangle$
}

DGGE conditions. Three of the "inshore" rockfish species, namely china, copper, and quillback rockfish (286 bp), contained identical 16S sequences spanning the region amplified with the $16 \mathrm{~S}$ primer set and were therefore indistinguishable. Although Brown rockfish was also indistinguishable from these three species via DGGE, it was distinguishable by sequencing (1-bp difference near the clamped end of the gene). In addition, the $16 \mathrm{~S}$ gene sequence for southern rocksole (300 bp) matched that of European flounder, plaice, starry flounder, and yellowtail flounder sequences; therefore this prey designation could include those species where applicable. For 29 of the standard prey fish, no corresponding 16S GenBank sequences were found, although these prey matched to the closest correct taxonomic group in GenBank. Three prey items did not genetically correspond to their identifications (cabezon, glass shrimp, and grunt sculpin). Prey nucleotide sequences we identified were submitted to GenBank under the accession numbers EU548087EU548272.

A second PCR-DGGE test based on the nuclear MHC class II B2 gene (Miller and Withler 1996) was developed to improve differentiation among the seven Salmonidae species. Although there were multiple MHC alleles for most of the salmon species, when combining the information with $16 \mathrm{~S}$ gene, all of the species were differentiable using PCR-DGGE. The B2 sequences (258-273 bp) from the salmon prey standards all clustered with those of the same species in GenBank. A PCR-DGGE test based on mitochondrial cytb was also used to aid in identifying rockfish species, which was difficult using 16 S alone. Multiple cytb alleles (284 bp) were observed in some species, but by using both $16 \mathrm{~S}$ and cytb, most rockfish species were differentiated by DGGE alone with the exception of black/yelloweye and quillback/brown rockfish. However, it should be noted that the allelic drop-out rate for both MHC class II B2 (72\% in the scats and $43 \%$ in the bones) and cytb (50\%) amplifications was considerably higher than for $16 \mathrm{~S}$. In the case of cytb, this is likely due to the amplification of larger sized fragments (427 bp for the primary product) from somewhat degraded scat DNA, whereas in the case of B2 (291-306 bp primary product), it may more likely be due to copy number differences between nuclear and mitochondrial DNA. Hence, in cases in which the secondary gene did not amplify, we did not conclude that the species was not present and merely went with the closest identification possible using $16 \mathrm{~S}$.

\section{Prey DNA identification from scat soft-part matrix}

Seventy-two scats from six subregions of the eastern Aleutian Islands and 70 scats from four subregions of British Columbia (Fig. 1) were analyzed for the presence of fish and cephalopod, as well as crustacean DNA (Table 4, Appendix D). Prey DNA remains were isolated from $78 \%(n=110)$ of scats, increasing to $87 \%(n=123)$ 
TABLE 4. Regional prey species (and crustacean) occurrences based on two concurrent identification methods.

\begin{tabular}{|c|c|c|c|c|}
\hline \multirow[b]{2}{*}{ Prey species } & \multicolumn{2}{|c|}{ British Columbia ( $n=54$ scats) } & \multicolumn{2}{|c|}{ Eastern Aleutians ( $n=56$ scats) } \\
\hline & Prey DNA & Prey hard parts & Prey DNA & Prey hard parts \\
\hline Walleye pollock & 1 & 16 & $10[3]$ & 20 \\
\hline Pacific cod & $11[1]$ & 13 & $7[3]$ & 9 \\
\hline Pacific hake & 6 & 19 & 0 & 0 \\
\hline Other Gadidae & 0 & 3 & 0 & 0 \\
\hline Salmonidae & $32[7]$ & 27 & $15[9]$ & 10 \\
\hline Pacific herring & $19[3]$ & 30 & 0 & 0 \\
\hline Pacific sand lance & 0 & 6 & 0 & 17 \\
\hline Other forage fish & $3[2]$ & 2 & 0 & 0 \\
\hline Scorpaenidae & $5[1]$ & 13 & $1[1]$ & 1 \\
\hline Arrowtooth flounder & 3 & 10 & $5[1]$ & 13 \\
\hline Sole/flounder group & $10[7]$ & 8 & $18[6]$ & 21 \\
\hline Other Pleuronectidae & $1[1]$ & 0 & 0 & 1 \\
\hline Cephalopoda & $1[1]$ & 4 & $8[5]$ & 6 \\
\hline Atka mackerel & 0 & 0 & $18[2]$ & 17 \\
\hline Other Hexagrammidae & $1[1]$ & 1 & $2[2]$ & 5 \\
\hline Elasmobranchii & 4 [3] & 21 & 7 [6] & 1 \\
\hline Plainfin midshipman & 0 & 9 & 0 & 0 \\
\hline Cyclopteridae & $2[2]$ & 0 & 7 [2] & 7 \\
\hline Cottidae & $1[1]$ & 0 & $3[2]$ & 13 \\
\hline Agonidae & $2[2]$ & 0 & $2[1]$ & 1 \\
\hline Pacific sandfish & 0 & 0 & 0 & 4 \\
\hline Lipiridae & 0 & 0 & 0 & 3 \\
\hline Remaining fish species & 4 & 5 & 4 & 4 \\
\hline All prey & $106[32]$ & 187 & $107[43]$ & 153 \\
\hline Crustaceans & 47 & $\mathrm{n} / \mathrm{a}$ & 5 & $\mathrm{n} / \mathrm{a}$ \\
\hline
\end{tabular}

Notes: The total number of occurrences unique to prey DNA identification using scat softpart matrix (undetected by prey hard-part identification in the same scat) are given in square brackets. The sole/flounder group contains three subfamilies: Hippoglossoidinae, Lyopsettinae, and Pleuronectinae.

success with the inclusion of crustacean DNA identifications. Rates of prey identification in scats considered "old" vs. "fresh" were both consistently high in the eastern Aleutian Islands ( $72 \%$ of 25 old scats vs. $85 \%$ of 47 fresh scats). However, old scats in BC had a lower extraction success (52\% of 23 old scats vs. $89 \%$ of 47 fresh scats).

After all scats were analyzed via PCR-DGGE using the16S prey standard sets, individual scat bands were excised and sequenced to confirm their respective identities and gauge DGGE scoring success. Of the 65 prey items (72 alleles) included in the $16 \mathrm{~S}$ fish prey standards, 34 were identified in the 142 analyzed scats, along with nine prey species for which standards had not been previously developed. Twenty-five percent of the scats contained species not present in the standards, which were classified as DGGE "unknowns" and subsequently identified through direct sequencing and querying the GenBank database via BLAST. The species identified through best matching protocols in GenBank but not present in the original standard included arctic char, Atlantic salmon, littlemouth flounder, rock greenling, smooth lumpsucker, sturgeon poacher, threadfin sculpin, yellow irish lord, and an unidentified sculpin. New alleles were found for 18 species, yielding a total of 115 alleles in the $16 \mathrm{~S}$ fish data set. In $91 \%$ of cases in which bands aligned with standards, individual prey species were identified correctly to species using DGGE alone (for cases in which a prey band matched the fish standard under both sets of conditions; Table 3).

\section{Comparison of prey occurrences using morphological hard-part and soft-part DNA identification}

A disproportionate number of the 32 scats that amplified no prey DNA were highly desiccated and considered old. Hard parts identified 61 prey occurrences within these scats. The following comparisons exclude these samples and concentrate on a direct comparison of the 110 scats for which the amplification of prey DNA from scat soft-part matrix was successful.

An average of 1.94 prey occurrences per scat (213 occurrences, range 1-5) were detected by DNA methods, while prey hard parts identified 340 prey occurrences (60\% more), resulting in a mean of 3.09 prey occurrences per scat (range 1-10; Table 4). Otolith and beak identification alone accounted for just 41 prey hard-part occurrences, while other diagnostic prey hard parts accounted for the remaining prey occurrences. Prey occurrences between techniques matched in 138 cases, with identical species composition within an individual scat in $20 \%$ of scats. These matching composition scats had either one $(73 \%)$ or two $(27 \%)$ species present. Hard parts therefore identified 202 incidences of prey undetected by DNA identification in $70 \%$ of scats, while DNA 
identified 75 additional prey incidences in 48 scats (44\%) for which no hard-part evidence for that prey had been found, increasing the total number of prey occurrences by $22 \%$ across the 110 scats compared (and by 19\% across all 142 scats). While no new prey families were detected, DNA did identify occurrences of four prey species/genera (Appendix D) previously unreported in Steller sea lion diet studies: Atlantic salmon and northern spearnose poacher (100\% GenBank sequence matches), arctic char $(98 \%$ GenBank sequence match, Salvelinus sp.), and littlemouth flounder (best GenBank match, possible Pseudopleuronectes sp.).

The 75 unique DNA related prey occurrences included species within 16 of the 22 prey groupings, but most were Salmonidae and Pleuronectidae (mainly the sole/flounder grouping), followed by Elasmobranchii and Cephalopoda (Fig. 3). Despite the resulting 10-15\% FO increases for some species groupings (Fig. 3), there was no significant difference between regional diet composition based on hard-part identification alone compared to that using both identification techniques combined (BC, chi-square, $\chi_{18}=8.6, P>0.95$; EA, chisquare, $\chi_{16}=6.4, P>0.98$; Fig. 4 ). When the two prey identification techniques were compared directly using the percentage of modified frequency of occurrence (\%MFO), species group rankings by region were not significantly different (Spearman rank, BC, $P=0.59$; EA, $P=0.69)$, but occurrence-based diet composition rankings were $\left(\mathrm{BC}\right.$, chi-square, $\chi_{18}=51.7, P<0.001$; EA, chi-square, $\chi_{16}=39.0, P<0.005$; Fig. 4 , Appendix D), partly due to those additional occurrences unique to DNA (notably Salmonidae), but also due to 23 Pacific sand lance and nine plainfin midshipman occurrences detected only by hard parts. In addition to these two species, walleye pollock, arrowtooth flounder, Elasmobranchii (BC only), Pacific hake (BC only), and Cottidae (EA only) were all proportionally more dominant using hard-part identification (Fig. 4, Appendix D).

In 49 cases (14\%), DNA identification increased the resolution compared to morphological prey hard-part identification. More than half (55\%) of these cases arose from species-level identification of Salmonidae using DNA (none of which could be classified to species using hard-part identification), with most of the remainder through identifying Cephalopoda, Rajidae, and Scorpaenidae (mainly rockfish) to species (Appendix D). DNA methods identified spot prawns comprising the majority of the many species of crustaceans found across the BC sites ( $45 \%$ of the 47 crustaceans amplified). Some others identified were Cancridae sp. (9\%), dungeness crab (9\%), and Petrolisthes sp. (13\%). Crustaceans were detected in only five EA scats (Appendix D).

Regional differences in diet composition based on both identification methods combined (chi-square, $\chi_{21}=$ $151.4, P<0.001)$ reflected high occurrence contributions by Pacific herring, salmon, and gadids (notably Pacific hake) in $\mathrm{BC}$, while Pleuronectids, walleye

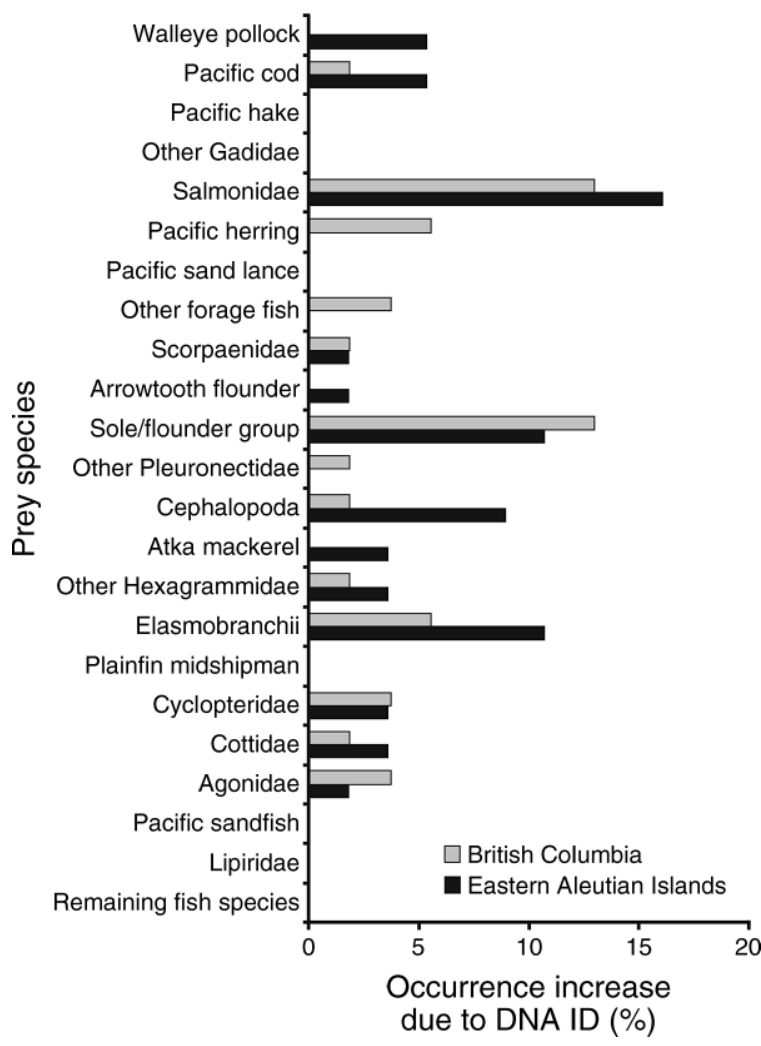

FIG. 3. Absolute increase to hard-part identification percentage frequency of occurrence of major prey groupings after the inclusion of 75 unique prey DNA identifications based on 110 Steller sea lion scats from British Columbia and the eastern Aleutian Islands.

pollock, Atka mackerel, and salmon dominated in the eastern Aleutian Islands (Fig. 4).

\section{Species identification from archived Salmonidae hard parts using genetic techniques}

Identification of hard parts to the Salmonidae family within the 100 archived (1997-2002) sea lion scats relied mainly on gill rakers, as well as branchials, teeth, and otoliths, with species-specific resolution achieved in $6 \%$ of scats (those that contained otoliths in reasonable condition). In contrast, $95 \%$ of the individual hard-part DNA extractions amplified at least one of the two (16S and B2) loci, resulting in Salmonidae-specific species resolution based on DNA in $93 \%$ of scats. Eight of 238 hard parts morphologically identified as Salmonidae were identified via DNA as other species by $16 \mathrm{~S}$. Hard parts from four scats were not amplifiable. In total, 107 individual Salmonidae species identifications were made using DNA, and 19 more were coarsely resolved (typically down to one of two different Salmonidae species; Table 1). Fourteen scats contained two species of Salmonidae and three scats contained three species of Salmonidae. Three of the six species hard-part identifications were confirmed by DNA identification, with one 


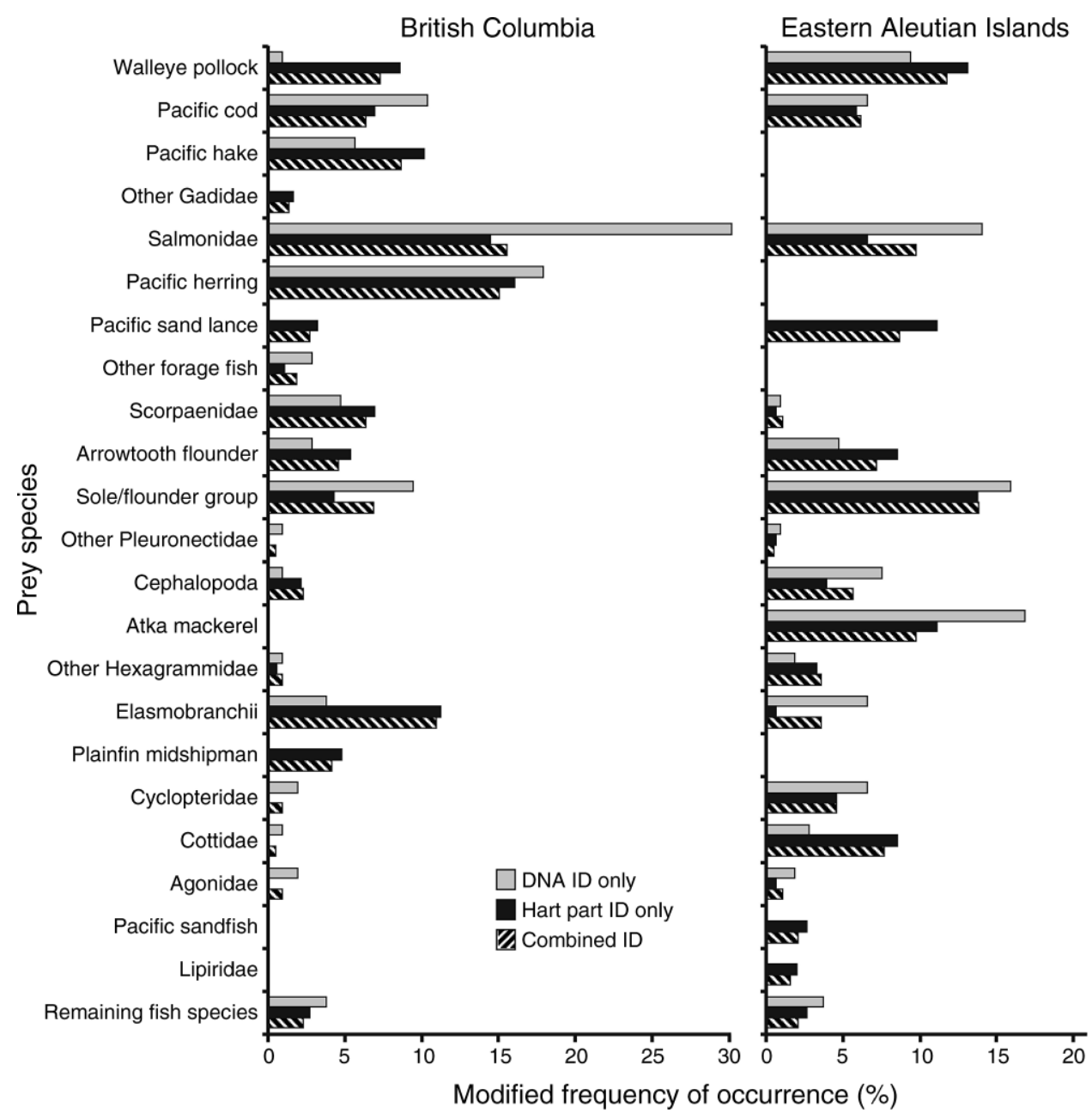

FIG. 4. Frequency of occurrence (modified to total 100\%) of major prey groupings based on 110 Steller sea lion scats from British Columbia and the eastern Aleutian Islands. Bars depict diet contribution based solely on prey DNA identification using scat soft-part matrix, solely on identification of prey hard parts, and an overall diet estimate, combining both identification methods.

non-match found and the remaining two being among the few hard parts not to amplify.

The combination of DNA analysis of these archived Salmonidae hard parts and the 47 DNA identifications of Salmonidae from the scat soft-matrix samples (Appendix D) provides the most detailed assessment of the different species of Salmonidae eaten by Steller sea lions to date (Table 1). Overall, seven species of Salmonidae (including Atlantic salmon) were detected ( $n=200$ occurrences). Geographical and temporal differences were apparent, but overall, pink (35\%) and chum $(29 \%)$ salmon were the most important species, followed by chinook salmon (14\%). Chum dominated in the May 2005 eastern Aleutian samples, while pink and coho salmon were featured in Frederick Sound (southeastern Alaska [SEAK]), with chinook also detected in December. In BC, pink (36\%) and chum (32\%) dominated, followed by chinook (14\%, Table 1). Salmon were estimated to be mainly $30-59 \mathrm{~cm}$ in length based on sizes of diagnostic hard parts $(91 \%$ in $\mathrm{BC}, 83 \%$ in SEAK, and $75 \%$ in EA).

\section{DisCUSSION}

Ecological studies require accurate information about what species eat, which is especially difficult to acquire for marine mammals. Prey hard parts identified in stomachs and scat samples can potentially provide reasonable quantitative estimates of diet composition, but they are not without limitations (Tollit et al. 2003, 2007, Pierce et al. 2004). Alternative non-morphological techniques to estimate diet are being developed, such as the analysis of long-chain fatty acids (Iverson et al. 2004, Beck et al. 2007) and stable-isotope ratios (Lawson and Hobson 2000) in tissues of predators and prey and most recently DNA analysis of scat remains (Jarman et al. 2002, Purcell et al. 2004, Casper et al. 2007b), and these can provide valuable comparative diet composition data.

We successfully developed and applied group-specific nested PCR primers, high-resolution DGGE, and 
BLAST program sequence matching for recovering and analyzing prey DNA from scat material collected from wild Steller sea lions. Prey DNA degradation during digestion and low concentration of prey DNA in scats can be a concern (Symondson 2002), but our extraction success rates were high for both scat soft-part matrix (up to $87 \%$ ) and Salmonidae hard parts $(95 \%)$ stored for 5-9 years. Extraction success was better for fresh scats than older desiccated scats, particularly in BC, where scats were collected in relatively hotter summer weather. Future DNA-based field studies should ideally target fresh or recently produced scats to maximize data generation.

The DNA of more than 40 species of fish and cephalopod prey (plus at least seven species of crustacean) were identified from 110 scat soft-part matrix subsamples, averaging approximately two prey species per scat and ranging up to five. To our knowledge, this level of prey identification in any predator has never before been achieved using molecular techniques (Symondson 2002, King et al. 2008) and clearly confirms that noninvasive DNA methods can provide valuable comparative prey occurrence data for pinnipeds. This is of particular relevance not only to diet studies of various pinniped species that produce scats with very few prey hard parts (Gales and Chael 1992, Fea et al. 1999), but is also likely to be applicable and useful to diet studies of marine piscivores generally (e.g., cetaceans, penguins, sea birds, fish).

One can draw several other important conclusions from our study, which should be treated with appropriate caution until larger sample sizes are considered and these DNA methods are more fully assessed. First, DNA increased the number of occurrences and taxonomic resolution of some families compared to hard-part identification, resulting in an $\sim 20 \%$ increase in total occurrence (mainly Salmonidae, Pleuronectidae, Elasmobranchii, and Cephalopoda). This resulted in increased species richness in nearly half the scats directly compared. Substantial increases in the amount of information attained by combining DNA-based and morphological analyses of diet samples has also been highlighted by Casper et al. (2007b) and Deagle et al. (2007). While none of the new DNA-based identities belonged to previously unreported prey families, very low level occurrences of several new genera/species were established, notably two occurrences of Atlantic salmon at Whaleback in the eastern Aleutian/Gulf of Alaska region, which presumably traveled to Alaska from a distant salmon farm in British Columbia or further south. Overall, we thus found no evidence from our DNA analyses for hard-part identification having substantially missed major dietary components in either region, nor consequently that the total combined diet estimate (by occurrence) differed dramatically from the estimate of diet based only on hard parts. Generally, this is a reassuring result for past Steller sea lion diet studies based on hard-part identification of scats. In particular, we found prey DNA identification appears most promising in improving the magnitude and resolution of salmonid-pinniped interactions.

Hard parts identified $60 \%$ more prey occurrences than DNA identification of prey tissue within scats that amplified prey DNA, with hard parts identifying the same prey in $65 \%$ of 213 DNA prey occurrences. In both regions, rankings between the two identification methods were similar, but the relative proportions of prey species occurrences in the diet were very different. We believe our results provide further evidence that hard parts found in scats are from a composite of many past meals (shown to be up to $7 \mathrm{~d}$ when eating Gadidae and even longer if cephalopods are consumed; Tollit et al. 2003), whereas prey present in scat soft-part matrix represent only the most recent feeding events (estimated to be diet over one to two days by both Deagle et al. [2005b] and Casper et al. [2007a]). The fact that prey matches between methods occurred most often when only one prey was present support this suggestion. The relatively lower interspecific passage rate variation observed for prey flesh (soft parts) is clearly an advantage when quantifying diet. In particular, our results also appear to confirm that hard remains can overrepresent prey with robust skeletal elements (e.g., Gadidae, Cottidae) compared with prey with fragile skeletons that survive the digestive process poorly (e.g., Salmonidae, Elasmobranchii). Of course, the size and manner in which prey species are consumed, as well as their robustness to digestion, will affect their subsequent detection in scats. Reports of adult salmon being torn up and partially consumed (with resulting loss of hard parts) are well documented (Pierce and Boyle 1991), and pinniped feeding on flatfish can also involve tearing the prey (D. J. Tollit, personal observation). Preferential regurgitation of hard parts of both cephalopods and large fish (Bigg and Fawcett 1985, Kiyota et al. 1999, Tollit et al. 2003, Gudmundson et al. 2006) may also help explain observed differences in detection across the two identification methods.

Hard-part identification is potentially very sensitive, and detections can be made based on a single scale, tooth, or gill raker. Sand lance (and plainfin midshipman) were only detected by hard parts and given that $16 \mathrm{~S}$ primers completely matched published sequences, their lack of detection via DNA analysis may highlight evidence of secondary prey ingestion (in which a small prey is eaten first by a predatory fish which is then consumed by a sea lion) or method sensitivity differences. Only one or two sand lance per scat were enumerated using diagnostic hard parts, and sand lance were always concurrent with the presence of predatory fish (e.g., Gadidae, flatfish, and Salmonidae). The consumption of one 10 -g sand lance may represent only $0.005 \%$ of a sea lion's daily ration, which may be beyond the detection limit of PCR, especially considering our use of "in-bag" hand homogenizing and subsampling of scats. Deagle et al. (2005b) reliably detected prey fed at 6\% (by mass), 
sampling "blended" scats after overnight soaking and stirring (a preferable homogenizing technique), but found meals were not consistently distributed within the matrix of pre-blended scats. Serial dilutions of prey DNA in a constant concentration of predator DNA should be undertaken, in combination with feeding experiments, to determine lower limit sensitivity levels and the length of time different prey are detected postconsumption. Given consistent sensitivity across species and group-specific primers, the ability to disregard trace (or secondary) predation is considered an advantage, unless many samples contain trace DNA amounts that are close to the detection threshold.

King et al. (2008) reviewed the pros and cons of different DNA-based approaches to molecular analysis of predation. Major areas of difficulty as well as sensitivity issues include short post-ingestion detection periods and cross-amplification, though good primer design and assay optimization can prevent these problems arising. In our study, primer specificity and binding efficiency were first tested against a large diverse prey catalogue, in addition to previous validations using captive feeding studies (Deagle et al. 2005b). This approach, coupled with dual-temperature DGGE and direct sequencing, reduced potential problems associated with haplotype diversity, allelic variation, PCR artifacts, and cryptic bands. However, a number of technical issues still warrant further study, such as the sensitivity levels and biases related to primer binding, for example due to mismatches (von Wintzingerode et al. 1997) and biases towards low GC content templates (Reysenbach et al. 1992, Dutton et al. 1993). Arrowtooth flounder and walleye pollock are both examples of fish prey with high GC content identified to a lesser degree in the DNA analysis. Species identification was best achieved using a combination of prey standard and sequencing matching. Notably, two species identified by nearest sequence matching protocols were outside (littlemouth flounder) or at the extremes (arctic char) of known geographical ranges. Thus, further genotyping of the $16 \mathrm{~S}$ region of a wider range of potential prey as well as assessing the effectiveness of the primers developed with an even broader suite of species is considered important for future studies.

Otolith presence in scats (often used as the sole means to identify fish prey in pinniped scats; Pierce and Boyle 1991) accounted for $<10 \%$ of the overall number of fish occurrences identified, reiterating the need for utilizing all hard-part structures when assessing Steller sea lion diet. This technique requires considerable skill and an extensive reference collection but can provide valuable information on size and number of prey consumed, which can be used to reconstruct biomass-based diet composition, considered the preferable quantification approach (Hammond and Rothery 1996, Laake et al. 2002, Tollit et al. 2007). Molecular techniques are easier tools to transfer and automate among laboratories, though DGGE is considered a difficult technique to master (King et al. 2008). DNA analysis on a combination of ground-up hard parts and soft remains may ultimately be the best means for determining diet. If subsequent detection efficiencies prove to be similar between the two identification methods, future choice of methods will depend on the need to determine prey size and biomass-based diet information, the availability (and speed) of laboratories capable of performing the needed analyses, and the cost per sample. Presently, the cost of running $\sim 400$ samples using $16 \mathrm{~S}$ analysis alone is identical to using hard-part identification. The inclusion of gene sequencing increases costs by two-thirds and if a second gene (to increase resolution of Salmonidae and Scorpaenidae) is required, by $30 \%$, though efficiencies increase if more samples are run. If more quantitative measures of prey abundance are required, potentially quantitative PCR (qPCR) methods could be developed further (Deagle and Tollit 2007, Matejusovka et al. 2008), but would likely be limited to specific, previously defined species groups (i.e., it would not work well to identify "unknown" prey or a large range of prey species). New microarray and pyrosequencing methodology could also be developed and be usefully applied in future diet studies (King et al. 2008).

In our study, DNA identification methods did not always resolve every prey to an individual species, yet for certain prey families and genera (particularly Salmonidae, as well as Scorpaenidae, Elasmobranchii, Cephalopda, and Gadidae), it was able to consistently increase taxonomic resolution compared to hard-part identification (see also Parsons et al. 2005), increasing the number of "confident" species identifications from $68 \%$ to $80 \%$ in our comparative study. Increased resolution of crustacean remains was also achieved, which presently are difficult to identify using hard-part remnants and often assumed to be present due to secondary prey. We found most crustacean occurrences did generally co-occur with predatory fish in the scats we analyzed. However, despite both regions containing similar predatory species, the BC samples contained an order of magnitude higher occurrences (of mainly shrimp and prawns) than the eastern Aleutian scats, perhaps reflecting either regional and temporal differences in fish diets or selection by sea lions.

The DNA methods we developed greatly increased the efficiency (from $6 \%$ to $93 \%$ ) of salmon species resolution of long-term archived Salmonidae hard parts. DNA methods were able to discern different species of salmon within the same scat, as well as different fish of the same species in the same scat (using multiple alleles), confirming previous DNA studies (e.g., Purcell et al. 2004, Kvitrud et al. 2005). The vast majority of hard parts identified morphologically as Salmonidae were subsequently confirmed as Salmonidae by DNA methods. Our study has provided high resolution of species of salmon currently important to Steller sea lions. Notwithstanding observed geographical and temporal differences, pink and chum salmon appear to be the most 
important Salmonidae species, followed by chinook salmon. The dominance of pink and chum salmon is unsurprising given their wide-scale abundance (Ruggerone and Nielson 2004), while the proportion of chinook in scats from BC and southeast Alaska may be indicative of prey selection.

Both identification techniques similarly highlighted regional differences in diet composition and confirm that Steller sea lions in BC waters consume mainly schooling prey (i.e., herring, salmon, dogfish, Pacific hake, walleye pollock, and Pacific sand lance), bottom fish (i.e., flatfish, rockfish, and skate), and some Cephalopoda (Bigg 1985, COSEWIC 2003). In the eastern Aleutians, walleye pollock, Atka mackerel, sole and flounder, salmon, Pacific cod, Pacific sand lance, sculpins, and Cephalopoda were important, comparable to the summer diet described using prey hard-part identifications from scats collected in 1990s (Sinclair and Zeppelin 2002). The geographical differences we observed in diet reiterate the need to collect sufficient scats $(\sim 70$ scats per site; Trites and Joy 2005) to detect regional as well as seasonal differences.

Molecular methods also exist to determine defecator sex, species, and even individual animals (Reed et al. 1997, Farrell et al. 2000, Ream 2001). Metabolic, reproductive, as well as stress hormones can be extracted from scats, along with information on metal contamination and parasite loads (e.g., Dailey et al. 1998, Hunt et al. 2004). Given the potential of such information, it would be prudent for scat-based diet studies to archive scat soft-part matrix for such future analyses.

In summary, molecular analysis of predation through PCR amplification of prey is a new and rapidly growing field, useful for both vertebrates and invertebrates within both aquatic and terrestrial systems (see reviews by Harper et al. 2005, Sheppard and Harwood 2005, King et al. 2008). Our results highlight the broad potential of group-specific PCR primers and DGGEbased prey identification to document the diet of generalist marine vertebrate predators using scat material collected in the wild. The unique DNA detections and increased resolution achieved highlight the benefits of using an integrated approach (especially for studies focused on salmon predation), while the resulting differences between techniques affords a much-needed assessment of potential biases, current limitations, and the merits of each. Ultimately, as DNA mass target detection systems improve, the resulting improved diet composition estimates (coupled with concurrent demographic information) will be of considerable benefit not only to scientists studying ecosystem trophic interactions, but also to marine wildlife conservationists and fisheries managers.

\section{ACKNOWLEDGMENTS}

Funding for this project was provided to the North Pacific Universities Marine Mammal Research Consortium by the National Oceanographic and Atmospheric Administration (Grant NA05NMF4391068) and the North Pacific Marine
Science Foundation and by support from the Department of Fisheries and Oceans Canada. We thank members of the Marine Mammal Research Unit (notably M. Davies and D. Gummeson) and the National Marine Mammal Laboratory (notably L. Fritz, T. Zeppelin, and S. Finneseth) for their expert logistical support, which was carried out under appropriate permits (NOAA NMML number 782-1532) and undertaken in accordance with UBC Animal Care Committee guidelines. We also thank E. Bowles, R. Casper, B. Deagle, B. Fadley, J. McKenzie, T. Zeppelin, and two anonymous referees for valuable comments on earlier drafts of the manuscript. Finally, we thank K. Wynne for support and members of Resource Assessment and Conservation Engineering Department, Archipelago Marine Research, and the Vancouver Aquarium for supplying prey samples.

\section{Literature Cited}

Beck, C. A., I. J. Iverson, and W. D. Bowen. 2007. Sex differences in grey seal diet reflect seasonal variation in foraging behaviour and reproductive expenditure: evidence from quantitative fatty acid signature analysis. Journal of Animal Ecology 76:490-502.

Benson, D. A., I. Karsch-Mizrachi, D. J. Lipman, J. Ostell, and D. L. Wheeler. 2005. GenBank. Nucleic Acids Research 33: D34-D38.

Bigg, M. A. 1985. Status of Steller sea lion (Eumetopias jubatus) and California sea lion (Zalophus californianus) in British Columbia. Canadian Special Publication of Fisheries and Aquatic Sciences 77:1-20.

Bigg, M. A., and I. Fawcett. 1985. Two biases in diet determination of northern fur seals (Callorhinus ursinus). Pages 284-291 in J. R. Beddington, R. J. H. Beverton, and D. M. Lavigne, editors. Marine mammals and fisheries. George Allen and Unwin, London, UK.

Bigg, M. A., and M. A. Perez. 1985. Modified volume: a frequency-volume method to assess marine mammal food habits. Pages 277-283 in J. R. Beddington, R. J. H. Beverton, and D. M. Lavigne, editors. Marine mammals and fisheries. George Allen and Unwin, London, UK.

Bowen, W. D. 2000. Reconstruction of pinniped diets: accounting for complete digestion of otoliths and cephalopod beaks. Canadian Journal of Fisheries and Aquatic Sciences 57:898-905.

Casper, R. M., S. N. Jarman, B. W. Deagle, N. J. Gales, and M. A. Hindell. 2007a. Detecting prey from DNA in predator scats: a comparison with morphological analysis, using Arctocephalus seals fed a known diet. Journal of Experimental Marine Biology and Ecology 347:144-154.

Casper, R. M., S. N. Jarman, N. J. Gales, and M. A. Hindell. 2007b. Combining DNA and morphological analyses of faecal samples improves insight into trophic interactions: a case study using a generalist predator. Marine Biology 152: 815-825.

COSEWIC [Committee on the Status of Endangered Wildlife in Canada]. 2003. COSEWIC assessment and update status report on the Steller sea lion Eumetopias jubatus in Canada. Committee on the Status of Endangered Wildlife in Canada, Ottawa, Ontario, Canada.

Dailey, M. D., R. V. Santangelo, and W. G. Gilmartin. 1988. A coprological survey of helminth parasites of the Hawaiian monk seal from the northwestern Hawaiian islands. Marine Mammal Science 4:125-131.

Deagle, B. E., N. J. Gales, K. Evans, S. N. Jarman, S. Robinson, R. Trebilco, and M. A. Hindell. 2007. Studying seabird diet through genetic analysis of faeces: a case study on macaroni penguins (Eudyptes chrysolophus). PLoS One 2(9): e831. [doi: 10.1371/journal.pone.0000831]

Deagle, B. E., S. N. Jarman, D. Pemberton, and N. J. Gales. 2005a. Genetic screening for prey in the gut contents from a giant squid (Architeuthis sp.). Journal of Heredity 96:417-423. 
Deagle, B. E., and D. J. Tollit. 2007. Quantitative analysis of prey DNA in pinniped faeces: Potential to estimate diet composition? Conservation Genetics 8:743-747.

Deagle, B. E., D. J. Tollit, S. N. Jarman, M. A. Hindell, A. W. Trites, and N. J. Gales. 2005b. Molecular scatology as a tool to study diet: analysis of prey DNA in scats from captive Steller sea lions. Molecular Ecology 14:1831-1842.

Dutton, C. M., C. Paynton, and S. Sommer. 1993. General method for amplifying regions of very high $\mathrm{G}+\mathrm{C}$ content. Nucleic Acids Research 21:2953-2954.

Farrell, L. E., J. Romant, and M. E. Sunquist. 2000. Dietary separation of sympatric carnivores identified by molecular analysis of scats. Molecular Ecology 9:1583-1590.

Fea, N. I., R. Harcourt, and C. Lalas. 1999. Seasonal variation in the diet of New Zealand fur seals (Arctocephalus forsteri) at Otago peninsula, New Zealand. Wildlife Research 26:147-160.

Ford, J. K. B., and G. M. Ellis. 2006. Selective foraging by fisheating killer whales Orcinus orca in British Columbia. Marine Ecology Progress Series 316:185-199.

Gales, N. J., and A. J. Chael. 1992. Estimates of diet composition of the Australian sea-lion (Neophoca cinerea) from scat analysis - an unreliable technique. Wildlife Research 19:447-451.

Gudmundson, C. J., T. K. Zeppelin, and R. R. Ream. 2006. Application of two methods for determining diet in northern fur seals (Callorhinus ursinus). Fishery Bulletin 104:445-455.

Hammond, P. S., and P. Rothery. 1996. Application of computer sampling in the estimation of seal diet. Journal of Applied Statistics 23:525-533.

Harper, G. L., R. A. King, C. S. Dodd, J. D. Harwood, D. M. Glen, M. W. Bruford, and W. O. C. Symondson. 2005. Rapid screening of invertebrate predators for multiple prey DNA targets. Molecular Ecology 14:819-827.

Höss, M., M. Kohn, S. Pääbo, F. Knauer, and W. Schröder. 1992. Excrement analysis by PCR. Nature 359:199.

Hunt, K. E., A. W. Trites, and S. K. Wasser. 2004. Validation of a fecal glucocorticoid assay for Steller sea lions (Eumetopias jubatus). Physiology and Behavior 80:595-601.

Iverson, S. J., C. Field, W. D. Bowen, and W. Blanchard. 2004. Quantitative fatty acid signature analysis: a new method of estimating predator diets. Ecological Monographs 74:211235.

Jarman, S. N., B. E. Deagle, and N. J. Gales. 2004. Groupspecific polymerase chain reaction for DNA-based analysis of species diversity and identity in dietary samples. Molecular Ecology 13:1313-1322.

Jarman, S. N., N. J. Gales, M. Tierney, P. C. Gill, and N. G. Elliott. 2002. A DNA-based method for identification of krill species and its application to analysing the diet of marine vertebrate predators. Molecular Ecology 11:26792690.

Jobling, M., and A. Breiby. 1986. The use and abuse of fish otoliths in studies of feeding habits of marine piscivores. Sarsia 71:265-274.

King, R. A., D. S. Read, M. Traugott, and W. O. C. Symondson. 2008. Molecular analysis of predation: a review of best practice for DNA-based approaches. Molecular Ecology 17:947-963.

Kiyota, M., C. Kawai, and N. Baba. 1999. Estimation of diet of male northern fur seals (Callorhinus ursinus) based on the analysis of fecal and regurgitated materials. Bulletin of the National Research Institute of Far Seas Fisheries 36:1-7.

Kvitrud, M. A., S. D. Riemer, R. F. Brown, M. R. Bellinger, and M. A. Banks. 2005. Pacific harbor seals (Phoca vitulina) and salmon: genetics presents hard numbers for elucidating predator-prey dynamics. Marine Biology 147:1459-1466.

Laake, J. L., P. Browne, R. L. DeLong, and H. R. Huber. 2002. Pinniped diet composition: a comparison of estimation indices. Fishery Bulletin 100:434-477.

Lawson, J. W., and K. A. Hobson. 2000. Diet of harp seals (Pagophilus groenlandicus) in nearshore northeast Newfoundland: inferences from stable-carbon $\left(\delta^{13} \mathrm{C}\right)$ and nitro- gen $\left(\delta^{15} \mathrm{~N}\right)$ isotope analyses. Marine Mammal Science 16: $578-591$.

Loughlin, T. R., A. S. Perlov, and V. A. Vladimirov. 1992. Range-wide survey and estimation of total number of Steller sea lions in 1989. Marine Mammal Science 8:220-239.

Matejusovka, I., F. Doig, S. J. Middlemas, S. Mackay, A. Douglas, J. D. Armstrong, C. O. Cunningham, and M. Snow. 2008. Using quantitative real-time PCR to detect salmonid prey in scats of grey Halichoerus grypus and harbour Phoca vitulina seals in Scotland: an experimental and field study. Journal of Applied Ecology 45:632-640.

Merrick, R. L., M. K. Chumbley, and G. V. Byrd. 1997. Diet diversity of Steller sea lions (Eumetopias jubatus) and their population decline in Alaska: a potential relationship. Canadian Journal of Fisheries and Aquatic Sciences 54: $1342-1348$.

Miller, K. M., and R. E. Withler. 1996. Sequence analysis of a polymorphic Mhc class II gene in Pacific salmon. Immunogenetics 43:337-351.

Murie, D. J., and D. M. Lavigne. 1986. Interpretation of otoliths in stomach content analyses of phocid seals: quantifying fish consumption. Canadian Journal of Zoology 64:1152-1157.

Myers, R. M., L. S. Fischer, L. S. Lerman, and T. Maniatis. 1985. Nearly all single base substitutions in DNA fragments joined to a GC-clamp can be detected by denaturing gradient gel electrophoresis. Nucleic Acids Research 13: 3131-3145.

Myers, R. M., T. Maniatis, and L. S. Lerman. 1987. Detection and localization of single base changes by denaturing gradient gel electrophoresis. Methods in Enzymology 155: 501-527.

Olesiuk, P. F., M. A. Bigg, G. M. Ellis, S. J. Crockford, and R. J. Wigen. 1990. An assessment of the feeding habits of harbour seals (Phoca vitulina) in the Strait of Georgia British Columbia based on scat analysis. Canadian Technical Report of Fisheries and Aquatic Sciences 1730.

Orr, A. J., J. L. Laake, M. I. Druv, A. S. Banks, R. L. DeLong, and H. R. Huber. 2003. Comparison of processing pinniped scat samples using a washing machine and nested sieves. Wildlife Society Bulletin 31:253-257.

Parsons, K. M., S. B. Piertney, S. J. Middlemas, P. S. Hammond, and J. D. Armstrong. 2005. DNA-based identification of salmonid prey species in seal faeces. Journal of Zoology 266:275-281.

Pierce, G. J., and P. R. Boyle. 1991. A review of methods for diet analysis in piscivorous marine mammals. Oceanography and Marine Biology 29:409-486.

Pierce, G. J., M. B. Santos, J. A. Learmonth, E. Mente, and G. Stowasser. 2004. Methods for dietary studies on marine mammals. Pages 29-36 in Investigating the roles of cetaceans in marine ecosystems. Scientific Exploration of the Mediterranean Sea Workshop Monographs 25. CIESM, Monaco.

Purcell, M., G. Mackey, E. LaHood, H. R. Huber, and L. Park. 2004. Molecular methods for the genetic identification of salmonid prey from Pacific harbor seal (Phoca vitulina richardsi) scat. Fishery Bulletin 102:213-220.

Rajakaruna, R. S., J. A. Brown, K. H. Kaukinen, and K. M. Miller. 2006. Major histocompatibility complex and kin discrimination in Atlantic salmon and Brook trout. Molecular Ecology 15:4569-4575.

Ream, R. R. 2001. Methods to determine gender and mitchondrial DNA haplotypes of Steller sea lions from fecal samples. Pages 71-73 in B. Fadley, editor. Steller sea lion investigations, 2000. U.S. Department of Commerce, Seattle, Washington, USA.

Reed, J. Z., D. J. Tollit, P. M. Thompson, and W. Amos. 1997. Molecular scatology, the use of molecular analysis to assign species, sex and individual identity to seal faeces. Molecular Ecology 6:225-234. 
Reysenbach, A., L. J. Giver, G. S. Wickham, and N. R. Pace. 1992. Differential amplification of rRNA genes by polymerase chain reaction. Applied Environmental Microbiology 58: 3417-3418.

Ruggerone, G. R., and J. L. Nielson. 2004. Evidence for competitive dominance of pink salmon (Oncorhynchus gorbuscha) over other salmonids in the North Pacific Ocean. Reviews in Fish Biology and Fisheries 14:371-390.

Sheppard, S. K., and J. D. Harwood. 2005. Advances in molecular ecology: tracking trophic links through predatorprey food-webs. Functional Ecology 19:751-762.

Sinclair, E. H., S. E. Moore, N. A. Friday, T. K. Zeppelin, and J. M. Waite. 2005. Do patterns of Steller sea lion (Eumetopias jubatus) diet, population trend and cetacean occurrence reflect oceanographic domains from the Alaska Peninsula to the central Aleutian Islands? Fisheries Oceanography 14(Supplement 1):223-242.

Sinclair, E. H., and T. K. Zeppelin. 2002. Seasonal and spatial differences in diet in the western stock of Steller sea lions (Eumetopias jubatus). Journal of Mammalogy 83:973-990.

Symondson, W. O. C. 2002. Molecular identification of prey in predator diets. Molecular Ecology 11:627-641.

Tollit, D. J., S. G. Heaslip, R. L. Barrick, and A. W. Trites. 2007. Impact of diet index selection and the digestion of prey hard parts on determining the diet of the Steller sea lion (Eumetopias jubatus). Journal of Zoology 85:1-15.

Tollit, D. J., S. G. Heaslip, B. E. Deagle, S. J. Iverson, R. Joy, D. A. S. Rosen, and A. W. Trites. 2006. Estimating diet composition in sea lions: Which technique to choose? Pages 293-308 in A. W. Trites, S. Atkinson, D. P. DeMaster, L. W. Fritz, T. S. Gelatt, L. D. Rea, and K. Wynne, editors. Sea lions of the world. Alaska Sea Grant College Program, University of Alaska, Fairbanks, Alaska, USA.
Tollit, D. J., S. G. Heaslip, and A. W. Trites. 2004. Sizes of walleye pollock (Theragra chalcogramma) consumed by the eastern stock of Steller sea lions (Eumetopias jubatus) in southeast Alaska from 1994 to 1999. Fishery Bulletin 102: $522-532$.

Tollit, D. J., M. Wong, A. J. Winship, D. A. S. Rosen, and A. W. Trites. 2003. Quantifying errors associated with using prey skeletal structures from fecal samples to determine the diet of the Steller sea lion (Eumetopias jubatus). Marine Mammal Science 19:724-744.

Trites, A. W., D. G. Calkins, and A. J. Winship. 2007. Diet of Steller sea lions (Eumetopias jubatus) in southeast Alaska from 1993-1999. Fishery Bulletin 105:234-248.

Trites, A. W., and R. Joy. 2005. Dietary analysis from fecal samples: How many scats are enough? Journal of Mammalogy 86:704-712.

Trites, A. W., and P. A. Larkin. 1996. Changes in the abundance of Steller sea lions (Eumetopias jubatus) in Alaska from 1956 to 1992: How many were there? Aquatic Mammals 22:153-166.

Von Wintzingerode, F. V., U. B. Goebel, and E. Stackebrandt. 1997. Determination of microbial diversity in environmental samples: pitfalls of PCR-based rRNA analysis. FEMS Microbiology Review 21:213-229.

Winship, A. J., and A. W. Trites. 2003. Prey consumption of Steller sea lions (Eumetopias jubatus) off Alaska: How much prey do they require? Fishery Bulletin 101:147-163.

Zeppelin, T. K., D. J. Tollit, K. A. Call, T. J. Orchard, and C. J. Gudmundson. 2004. Sizes of walleye pollock and Atka mackerel consumed by the western stock of Steller sea lions in Alaska from 1998-2000. Fishery Bulletin 102:509-521.

\section{APPENDIX A}

Primers designed and used in the soft scat and bone analysis (Ecological Archives A019-037-A1).

\section{APPENDIX B}

Detailed molecular techniques used in prey DNA identification analyses (Ecological Archives A019-037-A2).

\section{APPENDIX C}

Neighbor-joining bootstrapped dendograms of the mitochondrial 16S gene constructed using the Jukes Cantor correction (Ecological Archives A019-037-A3).

\section{APPENDIX D}

Prey and crustacean occurrences by region and scat collection site using concurrent DNA methods on scat soft-part matrix and prey hard-part identification analysis (Ecological Archives A019-037-A4). 